Неміш І.Л., Ступницька Г.Я., Федів О.І.

\title{
Індекс БОДЕ та функція зовнішнього дихання у хворих на хронічне обструктивне захворювання легень у посднанні зі стабільним хронічним коронарним синдромом
}

\author{
ВДНЗ України «Буковинський державний медичний університет», м. Чернівці, Україна
}

Одним 3 актуальних та проблемних питань сьогодення $\epsilon$ вплив надмірної маси тіла на показники функції зовнішнього дихання (ФЗД) у хворих із хронічним обструктивним захворюванням легень (ХОЗЛ) та стабільним хронічним коронарним синдромом (ХКС). Окремі автори описують дані щодо кращої прогностичної виживаності та меншої кількості загострень у хворих із ХОЗЛ та індексом маси тіла (IMT) від 25 до 29,9 кг/м² [3,4]. У літературі також зустрічаються дослідження, пов'язані iз нижчою загальною та кардіоваскулярною смертністю у пацієнтів зі стабільним ХКС [1,2]. Тому питання протективної ролі надмірної маси тіла на показники ФЗД залишається дискусійним і потребує подальших досліджень у хворих за умов коморбідного поєднання ХОЗЛ та стабільного ХКС.

Метою нашого дослідження було оцінити та порівняти показники біоімпедансометрії, дані спірометрії та індексу BODE у хворих із ХОЗЛ та стабільним ХКС.

Матеріали та методи. У дослідження були включені 40 пацієнтів із ХОЗЛ групи В, C; GOLD II, III та стабільним ХКС. Середній вік пацієнтів складав $63,22 \pm 11,96$. Хворих з ХОЗЛ та ХКС було поділено на групи залежно від IMT (класифікація ВОО3, 1997). До першої групи входило 20 пацієнтів 3 нормальною масою тіла $(18,5<\mathrm{IMT}<24,9)$, до другої - 20 обстежуваних із надмірною вагою $(25<\mathrm{IMT}<29,9)$. Усім хворим було проведено оцінку параметрів ФЗД за допомогою комп'ютерного спірографа "BTL - Spiro Pro" (Великобританія) з подальшою оцінкою результатів після проведення бронходилятаційного тесту з $\beta 2$-агоністом короткої дії (сальбутамолом у дозі 400 мкг). Визначення основних показників біоімпедансного аналізу проводили 3 використанням портативного апарату TANITA BC-601, (Японія). Для оцінки індексу BODE користувалися значеннями IMT, OФВ 1, mMRC та тесту з 6-хвилинною ходьбою. Статистичну обробку здійснювали за допомогою програми SPSS Statistica 23.

Результати. В результаті проведеної біоімпедансометрії виявилось, що у хворих другої групи відсоток жирової маси був вірогідно вищим $(\mathrm{p}<0,0001)$ у порівнянні 3 пацієнтами першої групи. Наявність статистично значущої відмінності між м'язовою масою у даних групах виявлено не було. У хворих із надмірною масою тіла значення ОФВ 1 було вірогідно вищим у порівнянні 3 обстежуваними із нормальною масою тіла $(\mathrm{p}=0,026)$. Також у хворих другої групи було відмічено вірогідно нижчі показники вираженості задишки по шкалі (mMRC) $(\mathrm{p}=0,015)$ у порівнянні з першою групою. При оцінці тесту з 6-хвилинною ходьбою відстань пройдена у метрах була вірогідно вищою у другій $(p=0,024)$ групі хворих у порівнянні з обстежуваними із нормальною масою тіла. Аналізуючи значення індексу BODE, було відмічено вірогідно нижчі показники у хворих з надмірною масою тіла $(\mathrm{p}=0.021)$ у порівнянні з обстежуваними з нормальною масою тіла.

Перспективи подальших досліджень. Робота в даному напрямку залишається актуальною, адже на сьогодні остаточно не з'ясована причина “парадоксу ожиріння" у хворих з ХКС та ХОЗЛ.

Висновки. У нашому дослідженні значення індексу BODE було вірогідно нижчим та показники ФЗД були вищими у хворих із нормальною масою тіла у порівнянні 3 пацієнтами із надмірною масою тіла. Дані результати дозволяють припустити кращу прогностичну виживаність у пацієнтів із ХОЗЛ, стабільним ХКС та надлишковою масою тіла.

Ключові слова: хронічне обструктивне захворювання легень, спірометрія, ожиріння.

\section{References}

1. Antonopoulos A.S., Oikonomou E.K., Antoniadeset C., et al. From the BMI paradox to the obesity paradox: the obesity-mortality association in coronary heart disease // Obes Rev. - 2016. - № 17(10). - P. 989-1000.

2. Oreopoulos A., McAlister F.A, Kalantar-Zadeh K., et al. The relationship between body mass index, treatment, and mortality in patients with established coronary artery disease: a report from APPROACH // Eur Heart J. - 2009. - № 30. P. 2584-2592.

3. Stoll P., Foerster S., Virchow J.C., et al. Overweight is a predictor of long-term survival in hospitalised patients with exacerbations of COPD // Respir. Med. - 2016. - № 116. - P. 59-62. 